\title{
Profiling of transcripts and proteins modulated by K-ras oncogene in the lung tissues of K-ras transgenic mice by omics approaches
}

\author{
SOJUNG LEE ${ }^{1 *}$, JUNGWOO KANG $^{1 *}$, MINCHUL CHO $^{1}$, EUNHEE SEO $^{1}, \mathrm{HEESOOK} \mathrm{CHOI}^{1}$, \\ EUNJIN KIM ${ }^{1}$, JUNGHEE KIM ${ }^{1}$, HEEJONG KIM ${ }^{1}$, GUM YONG KANG ${ }^{2}$, KWANG PYO KIM ${ }^{2}$, \\ YOUNG-HO PARK ${ }^{3}$, DAE-YEUL YU ${ }^{3}$, YOUNG NA YUM ${ }^{4}$, SUE-NIE PARK ${ }^{4}$ and DO-YOUNG YOON ${ }^{1}$
}

\begin{abstract}
Departments of ${ }^{1}$ Bioscience and Biotechnology and ${ }^{2}$ Molecular Biotechnology, Konkuk University, Hwayang-dong 1, Gwangjin-gu, Seoul 143-701; ${ }^{3}$ Animal Disease Model Research Center, Korea Research Institute of Bioscience and Biotechnology, Daejeon 305-333; ${ }^{4}$ Division of Genetic Toxicology, National Institute of Toxicological Research, Korea Food and Drug Administration, \#194 Tongil-Ro, Eunpyung-Gu, Seoul 122-704, Korea
\end{abstract}

Received August 7, 2008; Accepted October 13, 2008

DOI: 10.3892/ijo_00000138

\begin{abstract}
The mutated K-ras gene is involved in $\sim 30 \%$ of human cancers. In order to search for K-ras oncogeneinduced modulators in lung tissues of $\mathrm{K}$-ras transgenic mice, we performed microarray and proteomics (LC/ESI-MS/MS) analysis. Genes (RAB27b RAS family, IL-1RA, IL-33, chemokine ligand 6, epiregulin, EGF-like domain and cathepsin) related to cancer development (Wnt signaling pathway) and inflammation (chemokine/cytokine signaling pathway, Toll receptor signaling) were up-regulated while genes (troponin, tropomodulin 2, endothelial lipase, FGFR4, integrin $\alpha 8$ and adenylate cyclase 8 ) related to the tumor suppression such as 553 pathway, TGF- $\beta$ signaling pathway and cadherin signaling pathway were down-regulated by Kras oncogene. Proteomics approach revealed that upregulated proteins in lung adenomas of $\mathrm{K}$-ras mice were classified as follows: proteins related to the metabolism/ catabolism (increased from 7 to $22 \%$ by K-ras gene), proteins related to translation/transcription and nucleotide (from 4 to $6 \%$ ), proteins related to signal transduction (from 3 to $5 \%$ ),
\end{abstract}

Correspondence to: Dr Do-Young Yoon, Department of Bioscience and Biotechnology, Konkuk University, Hwayang-dong 1, Gwangjin-gu, Seoul 143-701, Korea

E-mail: dyyoon@kribb.re.kr

Dr Sue-Nie Park, Division of Genetic Toxicology, National Institute of Toxicological Research, Korea Food and Drug Administration, \#194 Tongil-Ro, Eunpyung-Gu, Seoul 122-704, Korea

E-mail: suenie@kfda.go.kr

${ }^{*}$ Contributed equally

Key words: proteomics, K-ras oncogene, microarray, Tg mouse, cancer proteins related to phosphorylation (from 1 to $2 \%$ ). ATP synthase, Ras oncogene family, cytochrome c oxidase, flavoprotein, TEF 1, adipoprotein A-1 BP, glutathione oxidase, fatty acid BP 4, diaphorase 1, MAPK4 and transgelin were up-regulated by K-ras oncogene. However, integrin $\alpha 1$, Rasinteracting protein (Rain), endothelin-converting enzyme-1d and splicing factor $3 \mathrm{~b}$ were down-regulated. These studies suggest that genes related to cancer development and inflammation were up-regulated while genes related to the tumor suppression were down-regulated by K-ras, resulting in the tumor growth. Putative biomarkers such as cell cycle related genes (Cdc37), cancer cell adhesion (Glycam 1, integrin $\alpha 8$, integrin $\alpha \mathrm{X}$ and Clec $4 \mathrm{n}$ ), signal transduction (Tlr2, IL-33, and Ccbp2), migration (Ccr1, Ccl6, and diaphorase 1 (Cyb5r3) and cancer development (epiregulin) can be useful for diagnosis and as prognosis markers and some of the target molecules can be applied for prevention of cancer.

\section{Introduction}

Lung cancer is the leading cause of cancer deaths worldwide (1). Mutations of K-ras gene have been demonstrated in $40-50 \%$ of lung cancer and activating mutations of the K-ras oncogene are found in one-quarter to one-half of human lung adenocarcinomas. K-ras is a member of the Ras family, the most common oncogenes activated in a wide range of human cancers. Research on Ras oncogene has established mutations of three members of Ras gene family in various human cancers of tissue and organs, including urinary bladder, mammary gland, rectum, kidney, liver, lung, ovary, pancreas, stomach and the hematopoietic system. Ras proteins are activated by diverse extracellular signals, for example, via integrins or growth factors such as epidermal growth factor (EGF) and platelet-derived growth factor (PDGF) that bind to their respective receptors with tyrosine-kinase activity, or by cytokines such as interleukin-2. Activated Ras proteins then pass the stimulating signal downstream via multiple effectors that can interact synergistically (2). Also, K-ras is a membrane- 
associated GTPase signaling protein that regulates proliferation, differentiation and cell survival (3). The frequency of K-ras mutation has been demonstrated to be considerably high in certain types of cancers $(4,5)$, such as in $75 \%$ of pancreatic tumors $(6,7), 45 \%$ of colorectal cancers (7) and $48 \%$ of lung cancer (8). Some studies have proposed that $\mathrm{K}$-ras mutations play a significant role in the onset and progression of lung cancer (9). In the mouse, K-ras mutations are found in $>90 \%$ of spontaneous and chemically-induced lung tumors (10). Currently, based on the results of molecular analysis of spontaneous and chemically-induced tumors in $\mathrm{K}$-ras, the mutation and overexpression of the transgene are considered to be the most probable mechanisms of enhanced carcinogenesis (11-13). Oncogenic K-ras is locked in an active form and is thus capable of activating downstream signaling cascades in the absence of external stimuli. K-ras activates effectors including the kinases Raf, PI3K, and MEKK, the GTPase Ral, and the signaling molecule AF6, which acts on gap junctions. K-ras signal transduction mediated by binding of growth factor, cytokines, or integrin also has interconnections with other major players in tumorigenesis, such as the Wnt signaling cascade (via $\beta$-catenin destruction complex) and the tumor suppressor p53 (14-16). In microarray and proteomics analyses, we confirmed that several genes and proteins related to cell growth, migration, cancer development, apoptosis, signaling pathway were up- and down-regulated by $\mathrm{K}$-ras oncogene. To confirm induction and development of cancer by mutants, we generated the Lox-Stop-Lox K-ras ${ }^{\mathrm{G} 12 \mathrm{D}}$ $\mathrm{Tg}$ mice, in which expression of oncogenic K-ras is controlled by a removable transcriptional termination Stop element (17). In this study, the focus was on the survey of genes and proteins regulated by K-ras in lung tissues of K-ras transgenic mice. For this reason, K-ras ${ }^{\mathrm{G} 12 \mathrm{D}}$ mouse was generated and the following experiments were performed as described in the Materials and methods section.

\section{Materials and methods}

Generation of K-ras transgenic mice and genotyping. K-ras ${ }^{\mathrm{G} 12 \mathrm{D}}$ $\mathrm{Tg}$ mice were established by the method of DNA microinjection into embryos of BDF1 mice, as previously described (18). Mutant K-ras ${ }^{\mathrm{G} 12 \mathrm{D}}$ gene expression vector carrying human surfactant protein C (SPC) promoter was used in order to regulate mutant $\mathrm{K}$-ras gene to be expressed in the lung. These mice were obtained for modulator analysis by K-ras mutant in mouse model of lung cancer. Genomic DNAs were extracted from Tg mice tails and PCR analysis was performed to analyze $\mathrm{K}$-ras gene expression. The cycling conditions were as follows: $94^{\circ} \mathrm{C}, 5 \mathrm{~min}$ followed by 30 cycles of $94^{\circ} \mathrm{C}, 30 \mathrm{sec}$; $60^{\circ} \mathrm{C}, 30 \mathrm{sec} ; 72^{\circ} \mathrm{C}, 30 \mathrm{sec}$ and $72^{\circ} \mathrm{C} 10 \mathrm{~min}$ in Takara PCR thermal cycler.

Histopathological examination. Tissue samples were fixed in $10 \%$ neutral-buffered formalin, embedded in paraffin, sectioned and stained with hematoxylin/eosin according to standard methods. The histopathological diagnoses were based on the criteria described by Frith and Ward (19).

Microarray analysis and hybridization. Gene expression analysis was conducted on the RNA samples from the lung tissues of K-ras Tg mice. Labeling and hybridization were performed by instruction of Affymetrix 4302.0 array chips (Affymetrix, Santa Clara, CA). Hybridization was performed at $55^{\circ} \mathrm{C}$ for $16 \mathrm{~h}$. After washing, the slide was dried by centrifugation at $800 \mathrm{rpm}$ for $3 \mathrm{~min}$ at RT. Hybridization images on the slides were scanned by Applied Biosystems 1700 Chemiluminescent Microarray Analyzer (Applied Biosystems, CA).

Proteomics analysis. Proteins were loaded on 4-20\% TrisGlycine Gel (Invitrogen, Carlsbad, CA). The gel pieces were excised in 10 bands according to molecular weight and digested with sequencing grade modified trypsin (Promega, Madison, WI) at $12.5 \mathrm{ng} / \mu \mathrm{l}$ in $50 \mathrm{mM} \mathrm{NH} \mathrm{HCO}_{3}$ buffer (pH 8.0) at $37^{\circ} \mathrm{C}$ for overnight. The resulting tryptic peptides were loaded onto a fused silica microcapillary column $(15 \mathrm{~cm}$ x $75 \mu \mathrm{m})$ packed with $\mathrm{C} 18(5 \mu \mathrm{m}, 200 \AA)$ reversed phase resin and were separated by LC using a linear gradient of $5-50 \%$ buffer $\mathrm{A}$ in $65 \mathrm{~min}$ followed by $50-90 \%$ buffer B in $5 \mathrm{~min}$ (buffer A: $0.1 \%$ formic acid in $\mathrm{H}_{2} \mathrm{O}$, buffer $\mathrm{B}$ : $0.1 \%$ formic acid in acetonitrile) at a flow rate of $250 \mathrm{nl} / \mathrm{min}$. The column was connected directly to LTQ ion-trap mass spectrometry (Thermo Finnigan, Waltham, MA) equipped with a nanoelectrospray ion source and the eluent peptides were dynamically selected for fragmentation by the operating software. Protein identification was performed by using Spectrum Mill Proteomics Workbench Version A.03.03 (Agilent Technologies). Data files were extracted using Spectrum Mill Data Extractor. Searches were carried out against the human NCBInr database in both forward and reverse directions using the Spectrum Mill program with the following parameters: specific to trypsin with two missed cleavage; $\pm 2.5 \mathrm{Da}$ precursor-ion tolerance; and $\pm 0.7 \mathrm{Da}$ fragment-ion tolerance. Carboxyamido-methylation of cysteine and oxidation of methionines were allowed as variable modifications. The initial results were auto-validated using the following parameters for details on the protein mode: SPI (scored percent intensity) $>70 \%$ for matches with score $>7$ for $+1,>9$ for $+1,>9$ for $+3,>8$ for +4 ; and SPI $>90 \%$ for score $>6$ on +1 . The proteins were summarized by validated peptides using the following parameters: $>13$ for protein score; SPI $>70 \%$ for score $>9$ on peptide; and each protein included at least 2 distinct peptide hits. A semiquantitative analysis of protein profile data was performed by comparing the total peptide intensity with the peptides of an identified protein. The total peptide intensity was obtained by summing up the peptide intensities of the peptide hits for the protein. False positive rates were calculated, as described previously (20).

RNA isolation and cDNA synthesis for Q-PCR analysis. Total RNAs were isolated from the lung tissue of K-ras oncogene transgenic mouse to measure the quantity of the various genes or proteins. The lungs of K-ras transgenic mouse and nontransgenic mouse were collected and lysed using both TRIzol (Invitrogen) and homogenizer machine. The mixture was transferred to a new e-tube and was grinded by $1 \mathrm{ml}$ needle. The mixture was centrifuged at $12,000 \mathrm{rpm}$ for $10 \mathrm{~min}$ to remove the tissue debris and the supernatants were transferred to a new e-tube. Chloroform $(200 \mu 1)$ was added into the mixture and vortexed and then incubated at room temperature 
Table I. Primer pairs used for real-time qPCR analysis of gene expression.

\begin{tabular}{|c|c|c|}
\hline Gene & Forward primer & Reverse primer \\
\hline Ccr1 & 5'-CAGAAGCCTACCCCACAACT-3' & 5'-CTAGGACATTGCCCACCACT-3' \\
\hline Ccl6 & 5'-TTATCCTTGTGGCTGTCCTTG-3' & 5'-CATGGGATCTGTGTGGCATA-3' \\
\hline IL-33 & 5'-TGGCCTCACCATAAGAAAGG-3' & 5'-GGATACTGCCAAGCAAGGAT-3' \\
\hline Itgax & 5'-TGGCTATCACACAGGCAACT-3' & 5'-TGCACAGTAGGACCACAAGC-3' \\
\hline Tlr2 & 5'-GGCTCTTCTGGATCTTGGTG-3' & 5'-TGTGAGTCCGGAGGGAATAG-3' \\
\hline Etfb & 5'-GCTGGCTGAAAAGGAGAAAG-3' & 5'-GTCACCTGAGAGGCGAATGT-3' \\
\hline $\mathrm{Nt} 5 \mathrm{c}$ & 5'-ACCGAGGTCTTCATCTGCAC-3' & 5'-CCACCGTCTTGTCCCTAGTC-3' \\
\hline Cyb5r3 & 5'-CTGTGTCGAGCGATGATGAC-3' & 5'-CGGAATTCAATGGTGTCTCC-3' \\
\hline Eef1b2 & 5'-GAGTGTGTCCGAAGCATTCA-3' & 5'-TCTTCCAGCATATCCGTTCC-3' \\
\hline Prdx3 & 5'-GAAAGAATGGTGGTTTGGGC-3' & 5'-TGCTTGACGACACCATTAGG-3' \\
\hline Ereg & 5'-GCAGTTATCAGCACAACCGT-3' & 5'-CAAGCAGTAGCCGTCCATGT-3' \\
\hline Add3 & 5'-TATTCAACACGCCCCGATGT-3' & 5'-CTGGTAGTCATAGTAGGCGA-3' \\
\hline Cdc37 & 5'-GAGGTAGAGGAGAAATGTGC-3' & 5'-GGTGGTCAGCGGTCTTGATC-3' \\
\hline Sdc1 & 5'-ATCTTTGCTGTGTGCCTGGT-3' & 5'-TAGAACTCCTCCTGCTTGGT-3' \\
\hline Anxa4 & 5'-CAGGATTCAACGCAACTGAA-3' & 5'-GGTGCTCTTGTAGGCACTCC-3' \\
\hline Clec4n & 5'-AATACTGAAGCGGAGCAGAA-3' & 5'-GCCAGAACCTGACATTTTGA-3' \\
\hline Glycam1 & 5'-CTCCCACCAGCTACACCAGT-3' & 5'-TCCTGGGCCTCTTGATTCTC-3' \\
\hline Ccbp2 & 5'-TGTAGTGACTATGCCCTTCT-3' & 5'-CCAGGTATTTGTCCAGGCTC-3' \\
\hline Xrn1 & 5'-ATGGGAAACAACAGGAATGG-3' & 5'-CAGCACATCAGGCACTCACT-3' \\
\hline Fgfr4 & 5'-GCCTTTCCTACCAGTCAGC-3' & 5'-GGAGCACAAGCAGAACCAGT-3' \\
\hline Itga8 & 5'-GACACCACCAACAACAGGAA-3' & 5'-TCTCCAGTGATACAAAGGGG-3' \\
\hline Tcrb-V13 & 5'-CTTGCCTCTCTTGACCACAG-3' & 5'-AGAGCCAGGGATGAAAAATG-3' \\
\hline Adcy8 & 5'-CGCAAATCGGAGGTAGTGAT-3' & 5'-TGCCAGTGAAAAAGCCTAGC-3' \\
\hline
\end{tabular}

for 10 min until the mixture was divided into two layers. The mixture was centrifuged at $12,000 \mathrm{rpm}$ for $10 \mathrm{~min}$ to remove the nuclear protein mixture. The supernatants were transferred to a new e-tube and $500 \mu 1$ isopropanol was added to condense the RNA pellet. The mixture was centrifuged at $12,000 \mathrm{rpm}$ for $20 \mathrm{~min}$ and the supernatants were discarded and then $1 \mathrm{ml}$ of $75 \%$ ethanol was added to wash the pellet. The mixture was centrifuged at $12,000 \mathrm{rpm}$ for $20 \mathrm{~min}$ and the supernatants were discarded. The pellet was dissolved in $100 \mu$ l diethylpyrocarbonate (DEPC)-treated water (Welgene, Daegu, Korea). Total RNAs were cleaned by RNeasy mini kit (Qiagen, Valencia, CA) according to the manufacturer's protocol. The concentration of RNAs was measured and $5 \mu \mathrm{g}$ each RNA was used to synthesize cDNA. RNAs were boiled for 2 min to unfold the secondary structure of RNAs. Three micrograms of oligo dT was added and the mixture was incubated at $65^{\circ} \mathrm{C}$ for $5 \mathrm{~min}$. This step indicated that oligo dT was attached to poly A tail of RNAs. After incubation, $5 \mu \mathrm{l}$ of 10X reverse transcription buffer (BioLabs, Ipswich, MA), reverse transcriptase (BioLabs), $250 \mu \mathrm{M}$ dNTP and DEPC water were added into the previous mixture at $42^{\circ} \mathrm{C}$ for $1 \mathrm{~h}$.

Quantitative real-time PCR. Real-time PCR was performed with relative quantification protocol on a MiniOpticon ${ }^{\mathrm{TM}}$ real-time PCR system (Bio-Rad, Hercules, CA), using iQ $^{\mathrm{TM}}$ SYBR ${ }^{\circledR}$-Green Supermix (Bio-Rad) for amplification detection. The real-time SYBR-Green assay was performed in a $20 \mu \mathrm{l}$ reaction mixture with $2 \mu \mathrm{l}$ of $25 \mathrm{X}$ diluted cDNA product, containing 1X iQ SYBR-Green Supermix (Bio-Rad) and $200 \mathrm{nM}$ each primer. The PCR amplification profile was as follows: initial denaturation at $95^{\circ} \mathrm{C}$ for $5 \mathrm{~min}$; 40 cycles at $95^{\circ} \mathrm{C}$ for $20 \mathrm{sec}$, Tm of samples for $20 \mathrm{sec}$ and $72^{\circ} \mathrm{C}$ for $20 \mathrm{sec}$. Optical data were collected after the annealing step of each cycle. Following PCR, reaction products were incubated for $1 \mathrm{~min}$ at $95^{\circ} \mathrm{C}$ and then at $55^{\circ} \mathrm{C}$. PCR products were melted between $55^{\circ} \mathrm{C}$ and $95^{\circ} \mathrm{C}$, then the temperature was increased up to $95^{\circ} \mathrm{C}$ in $0.2^{\circ} \mathrm{C}$ increments, 2 sec per increment. Optical data were collected over the duration of the temperature drop, with a dramatic increase in fluorescence occurring when the strands re-anneal. This was done to ensure that only one PCR product was amplified per reaction. Relative expression of the RT-PCR products was determined using the $\Delta \Delta \mathrm{Ct}$ method. This method calculates relative expression using the equation: Fold induction $=2^{\wedge}[-\Delta \Delta C t]$, where $C t$ is the threshold cycle, i.e. the cycle number at which the sample's relative fluorescence rises above the background fluorescence and $\Delta \Delta \mathrm{Ct}=[\mathrm{Ct}$ gene of interest (unknown sample) - Ct GAPDH (unknown sample)] - [Ct gene of interest (calibrator sample) - Ct CGAPDH (calibrator sample)]. Primers were purchased from M-biotech (Seoul, Korea). Primer pairs were chosen to minimize dimerization of primer and to generate an amplicon between 130 and $150 \mathrm{bp}$. All target genes were normalized to the housekeeping gene, glyceraldehyde 3-phosphate dehydrogenase (GAPDH), using primers (5'-ACCACAGTC CATGCCATCAC-3' as sense primer, 5'-TCCACCACCCTG TTGCTGTA-3' as antisense primer) and compared to normal mouse of the appropriate strain for relative expression values. One of the control samples, non-Tg mouse was chosen as the calibrator sample and used in each PCR. Each sample was run in triplicate and fold changes represent the ratio of $\mathrm{K}$-ras $\mathrm{Tg}$ mice to control (non-Tg mice) expression values. The sequences of the primers are listed in Table I. 
(A)

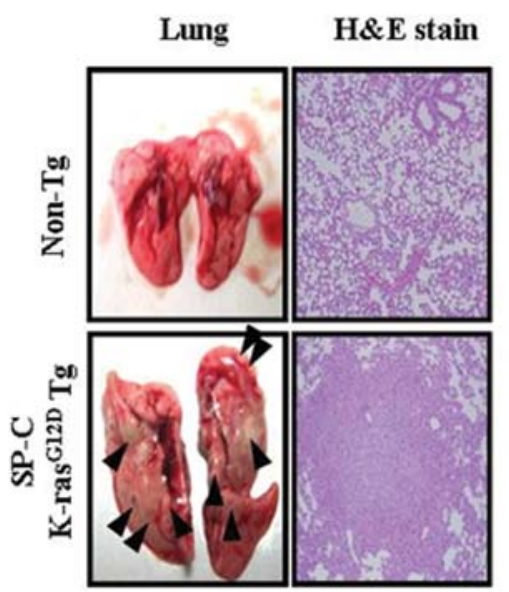

(B)

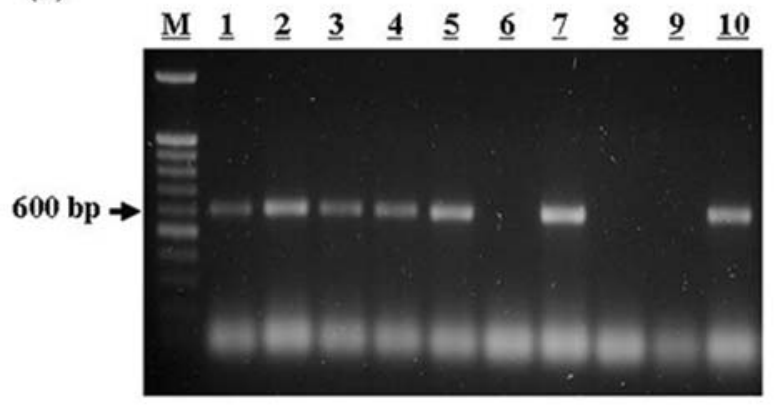

(C)

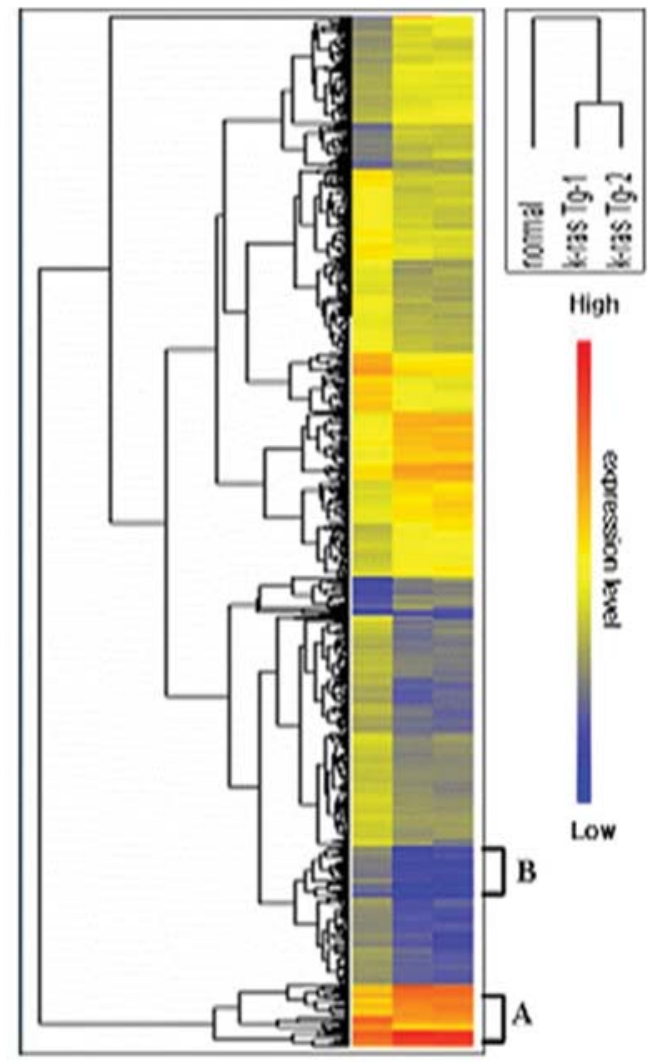

Figure 1. (A) Lung adenomas of K-ras Tg mouse. (B) Detection of K-ras gene expression by PCR in K-ras Tg mice. (C) Hierarchical clustering. Gene expression profiles of lungs of normal and K-ras Tg mice showing a distinct pattern. Most of the significantly up- and down-regulated genes are indicated in areas $\mathrm{A}$ and $\mathrm{B}$, respectively.

\section{Results}

Establishment of K-ras Tg mouse model and histopathological examination. Histopathologically, several alveolar/bronchiolar hyperplasias and adenomas were observed in each lobe of the lung in the K-ras Tg mice (Fig. 1A). Adenomas were induced as early as week 4 in all K-ras Tg mice. The size of K-ras gene product of PCR using genomic DNA was $\sim 600$ bp as expected in the lanes 1, 2, 3, 4, 5, 7 and 10 (Fig. 1B) and these $\mathrm{K}-$ ras $^{\mathrm{G} 12 \mathrm{D}} \mathrm{Tg}$ mice were used for analysis of K-ras modulators in mouse model of lung cancer and such genes were classified based on molecular function. Gene expression profiles of normal lungs and adenomas showed a distinct pattern in hierarchical clustering. Most of the up-regulated genes were included in area A of the hierarchical clustering and most of down-regulated genes were included in area B (Fig. 1C).

Profiling analysis of genes modulated by K-ras oncogene. We classified up- and down-regulated genes with known functions based on molecular function (Fig. 2A) and pathway (Fig. 2B) involved in biological processes. With regard to up-regulated genes involved in molecular function, the genes were classified into receptor, nucleic acid binding, defense/ immunity, oxidoreductase, kinase, hydrolase, etc. Also, downregulated genes involved in molecular function were classified into cytoskeleton proteins, transcription factor, extracellular matrix, etc. The classification based on pathway of K-ras induced genes includes $\mathrm{T}$-cell activation, toll receptor signaling, Wnt signaling, p53 pathway, inflammation mediated by chemokine and cytokine signaling, Alzheimer disease presenilin pathway, interleukin signaling, angiogenesis, apoptosis signaling pathway, etc. Down-regulated genes involved in pathway function were classified into inflammation mediated by chemokine and cytokine signaling, interleukin signaling, angiogenesis, Wnt signaling, TGF- $\beta$ signaling pathway, endothelin, PDGF signaling pathway, cadherin signaling pathway, etc. Many genes, of which expression are considered to be regulated by K-ras, were found in their expression pattern obtained from microarray in a highly consistent manner of K-ras regulation and 40 and 31 genes upand down-regulated by K-ras were selected for quantitative real-time PCR analysis (Table II).

Profiling analysis of protein modulated by K-ras oncogene. Proteins modulated by K-ras oncogene were analyzed by LC-ESI-MS/MS. Total 653 proteins up-regulated and 263 proteins down-regulated by K-ras were classified by fold change, as shown in Table III. Proteins up- and downregulated by K-ras in lung tissue in K-ras Tg mice are listed in Table IV. Proteins up- and down-regulated by K-ras oncogene were annotated by categories based on the GO (http://www.geneontology.org/): biological process using the house-made FindGo program as shown in Fig. 3. With regard to both up- and down-regulated proteins, the proteins were 


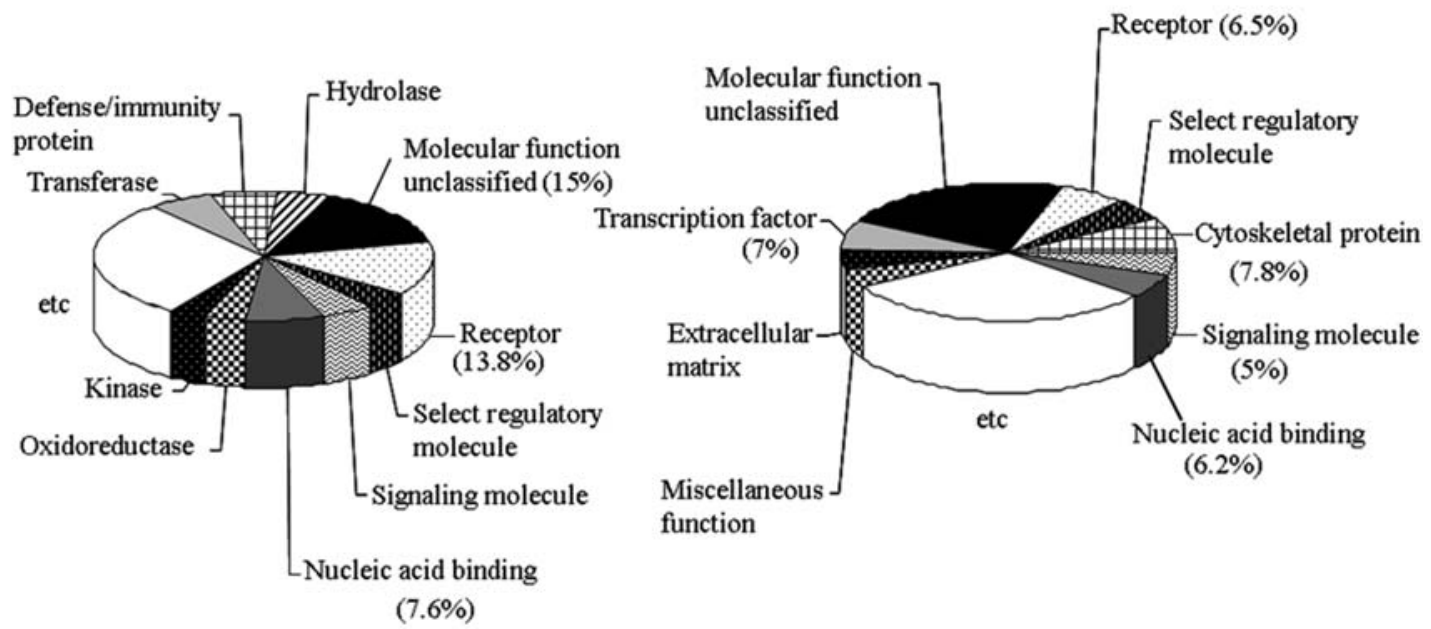

(B)

$(6 \%)$
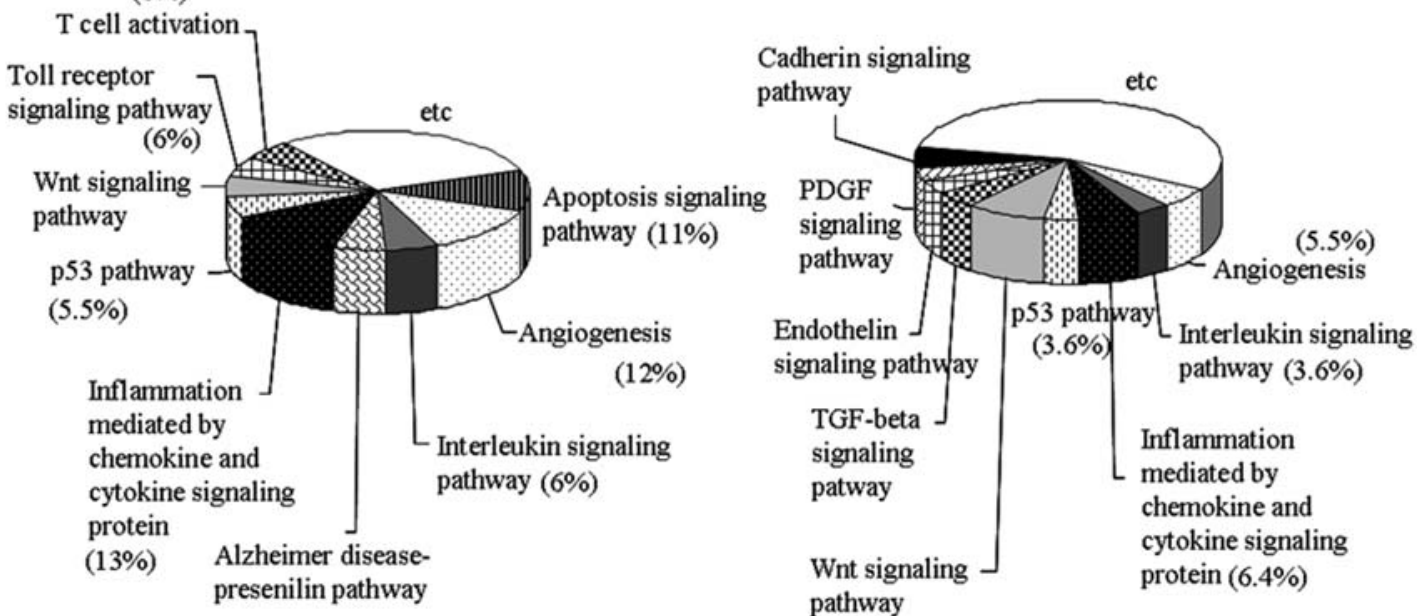

Figure 2. Pie charts showing gene classification based on molecular function (A) and pathway (B) of K-ras induced and down-regulated genes.

classified into proteolysis, cell adhesion, phosphorylation, development, cell cycle and cytokinesis, biological process, response, signal transduction, proliferation and apoptosis, translation and transcription and nucleotide, metabolism and catabolism, transport and localization, etc. Among the upregulated proteins, the proportion of proteins involved in metabolism and catabolism was large.

Validation of differentially expressed genes by real-time $q P C R$. To verify the microarray analysis, we measured the expression levels of genes regulated by K-ras oncogene using real-time qPCR with 1X iQ SYBR-Green Supermix (Bio$\mathrm{Rad})$. Total RNAs $(5 \mu \mathrm{g})$ were isolated from the lung tissues of normal and K-ras TG mice and 25X diluted cDNAs from total RNAs were used for real-time qPCR analysis. Non-TG mice were used as negative control in this experiment. The expression levels of epiregulin (Ereg), interleukin-33 (IL-33), integrin $\alpha \mathrm{X}(\mathrm{Itg} \alpha \mathrm{X})$ and annexin A4 (Anxa4) were significantly increased in the lung tissues of K-ras TG mice (>10-fold). We also confirmed that expression of genes regulated by $\mathrm{K}$-ras oncogene [chemokine (C-C motif) receptor 1 (Ccr1), chemokine (C-C motif) ligand 6 (Ccr6), toll-like receptor 2 (Tlr2), C-type lectin domain family 4 , member n (Clec4n), and 5',3'-nucleotidase, cytosolic (Nt5c)] were increased. Syndecan 1 (Sdc1), Cdc37 and glycosylationdependent cell adhesion molecule 1 (Glycam 1) were also increased 3.4-, 3.2- and 3.5-fold, respectively. Adducin 3 (Add3), electron transferring flavoprotein $\beta$ polypeptide (Etfb), 
Table II. Up- and down-regulation of genes by K-ras oncogene.

A, Genes up-regulated by K-ras oncogene

Regulation by K-ras Gene title

Fold change

\begin{tabular}{|c|c|c|}
\hline \multirow{40}{*}{$\mathrm{Up}$} & Epiregulin & 2.50 \\
\hline & Chemokine (C-C motif) ligand 6 & 2.11 \\
\hline & Interleukin-33 & 1.86 \\
\hline & $\alpha$ fetoprotein & 2.04 \\
\hline & Amphiregulin & 2.41 \\
\hline & Membrane-spanning 4-domains, subfamily A, member 6D & 2.32 \\
\hline & Serine/threonine kinase 39, STE20/SPS1 homolog (yeast) & 2.31 \\
\hline & ATPase, $\mathrm{H}+$ transporting, lysosomal V0 subunit D2 & 2.35 \\
\hline & S100 calcium binding protein $\mathrm{G}$ & 1.94 \\
\hline & Tumor necrosis factor (ligand) superfamily, member 9 & 2.22 \\
\hline & Sorting nexin 6 & 1.81 \\
\hline & Integrin $\alpha \mathrm{X}$ & 1.70 \\
\hline & RAB27b, member RAS oncogene family & 1.46 \\
\hline & Ras-related GTP binding D & 1.32 \\
\hline & C-type lectin domain family 4 , member $\mathrm{n}$ & 1.81 \\
\hline & Colony stimulating factor 2 receptor, $\beta 1$, low-affinity (granulocyte-macrophage) & 1.89 \\
\hline & Glutaredoxin & 1.47 \\
\hline & $\mathrm{SH} 2$ domain protein $1 \mathrm{~B} 1$ & 1.42 \\
\hline & Ankyrin 3, epithelial & 1.76 \\
\hline & Cathepsin $\mathrm{H}$ & 1.43 \\
\hline & Cathepsin $\mathrm{K}$ & 1.90 \\
\hline & Cathepsin C & 1.21 \\
\hline & Purinergic receptor P2Y, G-protein coupled 13 & 1.41 \\
\hline & Syndecan 1 & 1.33 \\
\hline & Leukotriene C4 synthase & 1.51 \\
\hline & Chemokine (C-C motif) receptor 1 & 1.27 \\
\hline & Chemokine (C-C motif) ligand 6 & 1.43 \\
\hline & Neurotrophin 5 & 1.30 \\
\hline & Toll-like receptor 2 & 1.66 \\
\hline & Interleukin 1 receptor antagonist & 1.02 \\
\hline & Histocompatibility 2, class II, locus Dma & 1.19 \\
\hline & HLA-B-associated transcript $1 \mathrm{~A}$ & 1.36 \\
\hline & Mannose receptor, C-type 1 & 1.37 \\
\hline & Protein arginine $\mathrm{N}$-methyltransferase 8 & 1.65 \\
\hline & C-type lectin domain family 4 , member a $2 / / /$-type lectin domain family 4 , member b1 & 1.19 \\
\hline & Caspase recruitment domain family, member 11 & 1.38 \\
\hline & Cytochrome b-245, $\beta$ polypeptide & 1.10 \\
\hline & Cytochrome c oxidase, subunit VI a, polypeptide 2 & 1.14 \\
\hline & Cadherin EGF LAG seven-pass G-type receptor 1 & 1.10 \\
\hline & EGF-like-domain, multiple & 1.28 \\
\hline
\end{tabular}

B, Genes down-regulated by K-ras oncogene

Regulation by K-ras Gene title

Fold change

Down

Insulin-like growth factor binding protein 2

Contactin 1

Adrenomedullin

Collagen and calcium binding EGF domains 1

Dynein, axonemal, intermediate chain 2

Titin

Latrophilin 3 
Table IIB. Continued.

\begin{tabular}{|c|c|c|}
\hline Regulation by K-ras & Gene title & Fold chang \\
\hline Down & $\begin{array}{l}5 \text { '-3' exoribonuclease } 1 \\
\text { Prostaglandin F receptor } \\
\text { Vav } 3 \text { oncogene } \\
\text { 8/notch-like EGF-related receptor } \\
\text { Cytochrome P450, family 2, subfamily d, polypeptide } 22 \\
\text { Tropomodulin } 2 \\
\text { ATP synthase, H+ transporting, mitochondrial F0 complex, subunits } \\
\text { Adenylate cyclase } 8 \\
\text { RAB36, member RAS oncogene family } \\
\text { Tropomyosin } 2 \\
\text { Calponin } 3 \text {, acidic } \\
\text { Troponin I, cardiac } \\
\text { Lactotransferrin } \\
\text { Follistatin } \\
\text { Annexin A8 } \\
\text { Troponin T2, cardiac } \\
\text { Chemokine binding protein } 2 \\
\text { T-cell receptor } \beta \text {, variable } 13 \\
\text { Lipase, endothelial } \\
\text { Fibroblast growth factor receptor } 4 \\
\text { Calcium channel, voltage-dependent, } 32 \text { subunit } \\
\text { Integrin } \alpha 8 \\
\text { Desmin }\end{array}$ & $\begin{array}{c}-1.52 \\
-1.44 \\
-1.39 \\
1.47 \\
-1.34 \\
-1.20 \\
1.15 \\
-1.16 \\
-1.30 \\
-1.31 \\
-1.15 \\
-1.20 \\
-1.47 \\
-1.26 \\
-1.19 \\
-1.14 \\
-1.11 \\
-1.07 \\
-1.12 \\
-1.19 \\
-1.04 \\
-1.24 \\
-1.17\end{array}$ \\
\hline
\end{tabular}

(A)

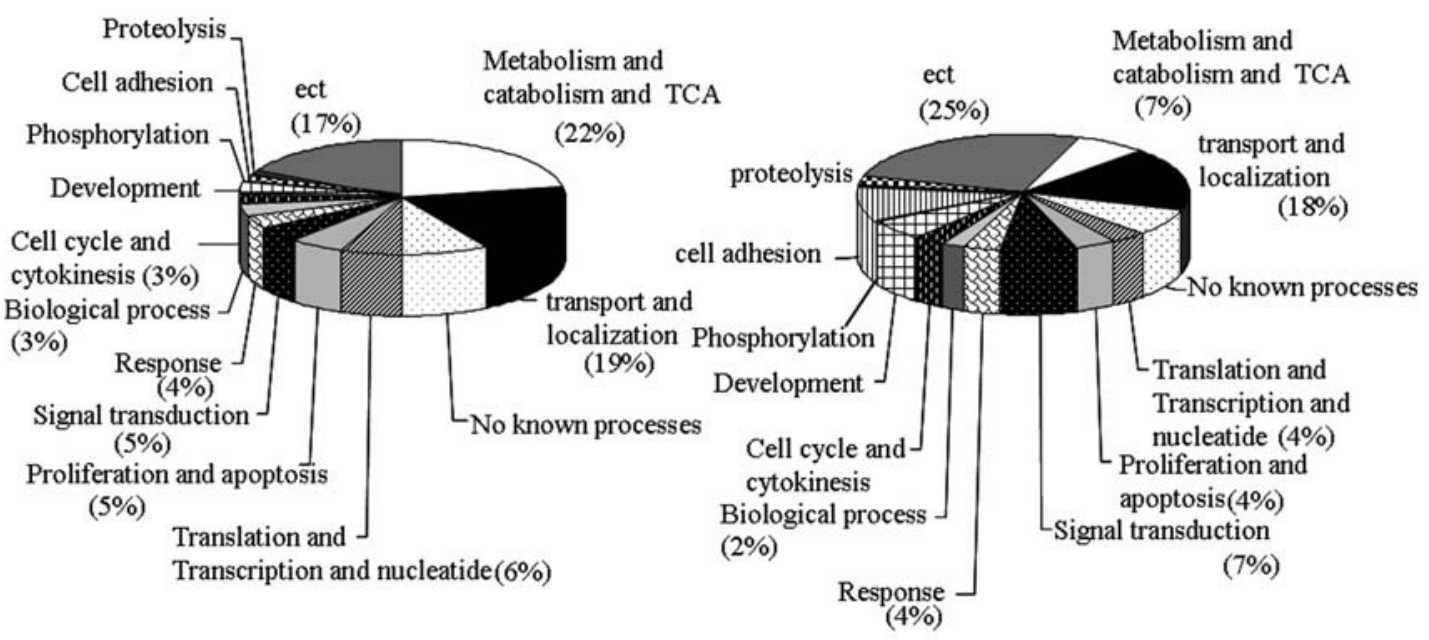

Figure 3. Pie charts showing classification of up-regulated proteins (A) and down-regulated proteins (B) in lung adenomas of K-ras Tg mice. Proteins up- and down-regulated by K-ras oncogene were annotated by categories based on the GO (http://www.geneontology.org/): biological function using the house-made FindGo program.

peroxiredoxin $3(\operatorname{Prdx} 3)$, eukaryotic translation elongation factor 1 B 2 (Eef1b2) and cytochrome b5 reductase 3 (Cyb5r3) were weakly increased (Fig. 4A). The expression levels of T-cell receptor $\beta$ V13 (Tcrb-V13), chemokine binding protein 2 (Ccbp2), 5'-3' exoribonuclease 1 (Xrn 1), integrin $\alpha 8$ (Itg $\alpha 8$ ), adenylate cyclase 8 (Adcy8), fibroblast growth factor receptor 4 (Fgfr4) were decreased by K-ras oncogene (Fig. 4B). 
(A)
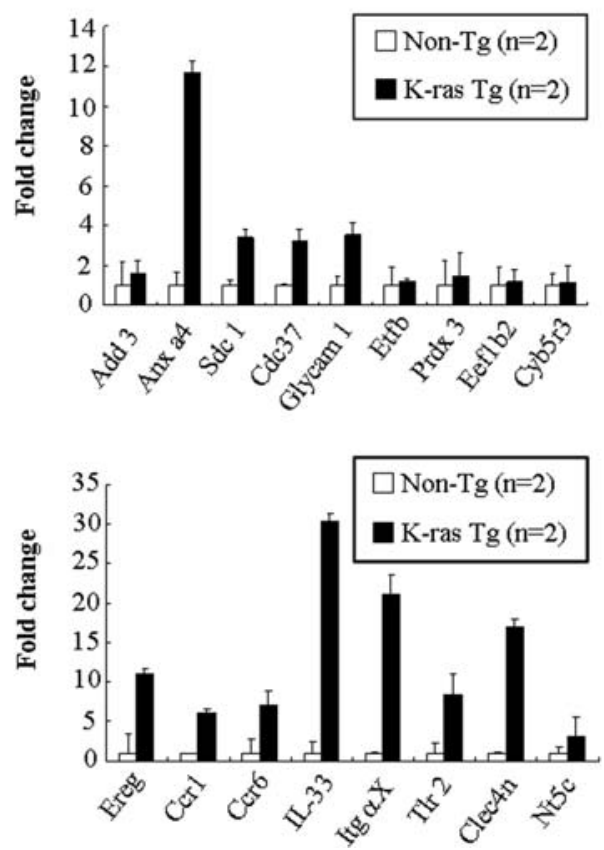

(B)

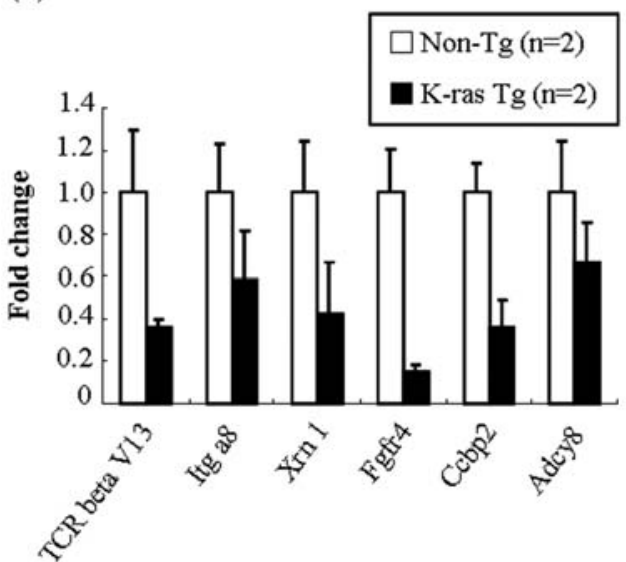

Figure 4. The expression level, which was obtained from Omics and real-time qPCR data of the selected as the candidates in the enhanced carcinogenesis in K-ras Tg mice. Genes up-regulated (A) and down-regulated (B) in lung adenomas of K-ras $\mathrm{Tg}$ mice. The gene expression level obtained from realtime qPCR was normalized by GAPDH. The respective fold changes were expressed by comparing with the values of non-Tg mice which were set as 1 . Data are mean \pm SD of two independent experiments, each performed in triplicates.

\section{Discussion}

The ras proteins are pivotal regulators of cellular proliferation, differentiation, motility, and apoptosis (21). K-ras oncogenes are frequently detected in mouse lung tumors (22-24). Activating point mutations in the K-ras gene have been found in $30-50 \%$ of human lung adenocarcinomas and are believed to play a key role in this malignancy (25). To analyze profiling of genes and proteins regulated by K-ras oncogene in lung tissue of K-ras Tg mice, K-ras ${ }^{\mathrm{G} 12 \mathrm{D}} \mathrm{Tg}$ mice, expressing mutant type K-ras gene in lung tissue by the regulation of SPC promoter sequence, were generated by the method of DNA
Table III. Proteomics analysis of protein profiling of lung proteins modulated by K-ras oncogene.

\begin{tabular}{lcc}
\hline & \multicolumn{2}{c}{ Mus musculus DB } \\
\cline { 2 - 3 } Fold change & Up-regulated & Down-regulated \\
\hline & & 48 \\
$<2$ & 40 & 48 \\
$2-4$ & 35 & 68 \\
$5-9$ & 19 & 41 \\
$>10$ & 559 & 79 \\
Total & 653 & 236 \\
\hline
\end{tabular}

Data files were extracted using Spectrum Mill Data Extractor with the parameters of $\left[\mathrm{MH}^{+}\right] 600$ to 40000 and minimum signal-to-noise $(\mathrm{S} / \mathrm{N})$ 25. Searches were carried out against the human NCBInr database in both forward and reverse directions using the Spectrum Mill program (Agilent Technologies) with the following parameters: specific to trypsin with two missed cleavage; \pm 2.5 Da precursor-ion tolerance; and $\pm 0.7 \mathrm{Da}$ fragment-ion tolerance. The initial results were auto-validated as described in the Materials and methods section.

microinjection into embryos of BDF1 mice as previously (18). $\mathrm{K}$-ras $\mathrm{Tg}$ mice and non-Tg mice were confirmed by PCR genotyping with detection of only transgene-specific sequence using genomic DNA. The K-ras gene was identified in transgenic mice. Total RNAs from the lung tissues of K-ras $\mathrm{Tg}$ mice were isolated and cDNAs were synthesized from RNAs. cDNA was used to analyze genes by using Affymetrix chips and proteins modulated by K-ras oncogene were analyzed by MALDI-TOF. In microarray analysis, the genes involved in the molecular function (nucleic acid binding, receptor and signaling molecule, etc.) and pathway (angiogenesis, inflammation mediated by chemokine and cytokine signaling, and apoptosis, etc.) were up-regulated, and the expression of several genes for biological processes showed a decreasing tendency in K-ras Tg mice. Also, proteins involved in metabolism and catabolism, transport and localization, proliferation and apoptosis, cell cycle, development were up-regulated by K-ras oncogene, whereas proteins were down-regulated by K-ras in metabolism and catabolism and (from 22 to 7\%), transport and localization (from 19 to $18 \%$ ), proliferation and apoptosis (from 5 to 4\%), translation and transcription and nucleotide (from 6 to 4\%). Genes and proteins related to carcinogenesis or K-ras mediated lung cancer were selected and the expression level of these genes was confirmed by real-time qPCR. The genes showed a similar expression pattern to the results of Omics analysis in real-time qPCR. Epiregulin, IL-33, integrin $\alpha \mathrm{X}$, toll-like receptor 2 , Clec $4 \mathrm{n}$ and annexin A4 as candidate genes responsible for the enhanced carcinogenesis in K-ras Tg mice were significantly up-regulated by K-ras oncogene. Epiregulin, the newest member of the family of EGF-like ligands, is present in some normal human tissues and cancer cell lines. It may be involved in normal growth development and in cancer progression (26). Recent studies have suggested that it is overexpressed in human prostate, colon, pancreatic and lung cancers (27-30). Toll-like receptor 2, a membrane receptor found at the surface of immune system 
Table IV. Up- and down-regulation of proteins by k-ras.

A, Proteins up-regulated by K-ras

Protein name

ATP synthase, $\mathrm{H}+$ transporting, mitochondrial F0 complex, subunit d

ATP synthase, $\mathrm{H}+$ transporting, mitochondrial F1F0 complex, subunit e ATP synthase F0 subunit 8

RAB7, member Ras oncogene family

RAB11B, member Ras oncogene family

RAB2, member Ras oncogene family

RAB18, member Ras oncogene family

Cytochrome b-5

Ubiquinol-cytochrome c reductase complex protein isoform 1

Cytochrome c oxidase subunit IV isoform 1

Cytochrome b5 outer mitochondrial membrane precursor

Cytochrome c oxidase, subunit VIb polypeptide 1

Cytochrome c oxidase, subunit $\mathrm{Vb}$

Cytochrome P450, family 2, subfamily b, polypeptide 10 isoform 1

\section{UMP-CMP kinase}

Proteasome activator subunit 2 isoform 1

Glutathione peroxidase

Glutathione peroxidase 3 precursor

Glutathione peroxidase 4 isoform 1 precursor

Microsomal glutathione S-transferase 1

Fatty acid binding protein 3 , muscle and heart

Fatty acid binding protein 4 , adipocyte

Ras suppressor protein 1 (Rsu-1) (RSP-1)

Related RAS viral (r-ras) oncogene homolog 2

$\mathrm{k}$-ras cellular oncogene

Ras suppressor protein 1 (Rsu-1) (RSP-1)

Voltage-dependent anion-selective channel protein 1

Voltage-dependent anion channel 2

Electron transfer flavoprotein subunit

$\alpha$, mitochondrial precursor

Electron transferring flavoprotein, $B$ polypeptide

Heat shock protein 1 (chaperonin)

Heat-shock protein $\beta-1$

Dodecenoyl-Coenzyme A $\delta$ isomerase

(3,2 trans-enoyl-Coenyme A isomerase)

Aacetyl-Coenzyme A acetyltransferase 3

Peroxiredoxin 5 precursor

Peroxiredoxin 3

Thioredoxin 1

Eukaryotic translation elongation factor $1 \gamma$

Eukaryotic translation elongation factor 1 B 2

Eukaryotic translation elongation factor $1 \delta$ isoform a

Vesicle-associated membrane protein, associated protein A

SEC22 vesicle trafficking protein-like 1

Histocompatibility 2, class II antigen A, B 1

H-2 class I histocompatibility antigen,

D-B $\alpha$ chain precursor [H-2D(B)] HLA-B-associated transcript $1 \mathrm{~A}$

Histocompatibility 2, class II antigen A, ß 1
Accession No.

Peptides unique No.

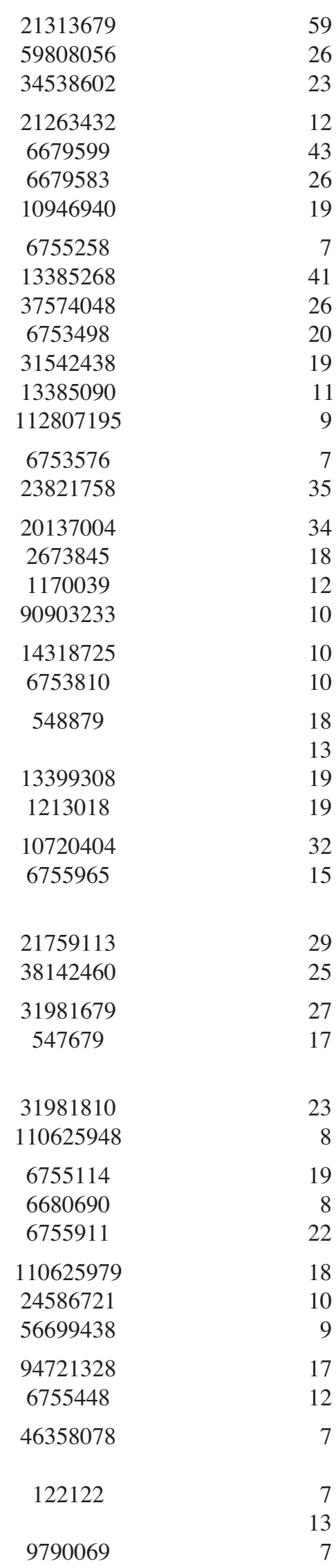

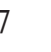


Table IVA. Continued.

\begin{tabular}{|c|c|c|}
\hline Protein name & Accession No. & Peptides unique No. \\
\hline Cell division cycle 37 homolog & 7949018 & 5 \\
\hline Apolipoprotein A-I binding protein & 21553309 & 4 \\
\hline Adducin $3(\gamma)$ & 31542111 & 2 \\
\hline Ribosomal protein, large P2 & 83745120 & 59 \\
\hline Chloride intracellular channel 5 & 27369886 & 32 \\
\hline Diaphorase 1 (cytochrome b5 reductase 3 ) & 19745150 & 32 \\
\hline Tumor-associated calcium signal transducer 1 & 112293275 & 5 \\
\hline Annexin A4 & 33416530 & 28 \\
\hline Tropomyosin 4 & 47894398 & 26 \\
\hline NADH dehydrogenase (ubiquinone) $1 \alpha$ subcomplex, 4 & 33563266 & 26 \\
\hline 6-phosphogluconolactonase & 13384778 & 25 \\
\hline Transgelin & 6755714 & 24 \\
\hline Guanine nucleotide-binding protein G(i) & 1730229 & 22 \\
\hline Transmembrane emp24-like trafficking protein 10 (yeast) & 40555903 & 20 \\
\hline SH3 domain binding glutamic acid-rich protein-like 3 & 18017602 & 20 \\
\hline Calpain small subunit 1 & 18202239 & 19 \\
\hline $\mathrm{S} 100$ calcium binding protein $\mathrm{G}$ & 14789635 & 15 \\
\hline Septin 2 & 6754816 & 14 \\
\hline Gelsolin-like capping protein & 110227377 & 14 \\
\hline Sideroflexin 3 & 16716499 & 14 \\
\hline Lactate dehydrogenase 2, B chain & 6678674 & 13 \\
\hline Mitogen activated protein kinase 3 & 21489933 & 13 \\
\hline Prenylcysteine oxidase 1 & 13385294 & 11 \\
\hline Sulfide:quinone oxidoreductase, mitochondrial precursor & 27151701 & 9 \\
\hline Galactokinase 1 & 29747831 & 6 \\
\hline Glycosylation & 33468855 & 6 \\
\hline
\end{tabular}

B, Proteins down-regulated by K-ras

\begin{tabular}{lcc}
\hline Protein name & Accession No. & Peptides unique No. \\
\hline Procollagen, type VI, $\alpha$ 2 & 22203747 & 6 \\
Complement component 3 & 28175786 & 5 \\
Pregnancy zone protein & 34785996 & 3 \\
Integrin $\alpha$ 1 & 84370023 & 3 \\
Ras-interacting protein 1 (Rain) & 81174999 & 2 \\
GAG12 & 29420429 & 2 \\
Splicing factor 3b, subunit 3 & 19527174 & 2 \\
Endothelin-converting enzyme 1d & 67810530 & 2 \\
\hline
\end{tabular}

cells, plays a role in signal transduction, immune response, induction of apoptosis $(31,32)$. It was reported that TLR2 might be used for immunotherapy of malignant tumors (33). IL-33 and Clec4n were involved in immune response and have cytokine and receptor activity, respectively. Clec $4 n$ has diverse functions, such as cell adhesion, signaling between cells $(34,35)$. The expression levels of syndecan 1 , chemokine (C-C motif) receptor 1, chemokine (C-C motif) ligand 6, cdc37 and glycam 1 were increased in $\mathrm{K}$-ras $\mathrm{Tg}$-mice. Syndecan, a cell surface proteoglycan, exhibits a molecular polymorphism during lung development (36). Syndecan 1 might be involved in pathogenesis of human lung cancer and non-small cell lung carcinoma $(37,38)$. Chemokine (C-C motif) receptor 1 and chemokine (C-C motif) ligand 6, which have an important role in the recruitment of leukocytes to the site of inflammation, promote tumorigenesis and metastasis, respectively (39). The migration and metastasis of tumor cells share many similarities with leukocyte trafficking, which is mainly regulated by chemokine receptor-ligand interactions (40). Glycam 1, a member of the glycoprotein mucin family and integrin $\alpha \mathrm{X}$ are involved in the cell adhesion and signal transduction $(41,42)$. Cdc37, an essential component of the sevenless receptor/mitogen-activated kinase protein (MAPK) signaling pathway, is involved in cell division cycle (43). The expression levels of Prdx3, Etfb, Eef1b2, Nt5c, and Cyb5r3 were weakly or negligibly increased by K-ras 
oncogene. Whereas, TCRb-V13, Ccbp2, Xrn 1, Itga8, Adcy8 and Fgfr4 were down-regulated in lung tissue of $\mathrm{K}$-ras $\mathrm{Tg}$ mice. $\mathrm{TCRb}-\mathrm{V} 13$ regulates cellular defense response and has receptor activity. Xrn1 is involved in 5' to 3' RNA degradation. This enzyme has also been identified as a candidate tumor suppressor gene in osteogenic sarcoma (44). Integrin $\alpha 8$ is known to regulate cell adhesion, migration, and proliferation. Adhesion of cells to extracellular matrix via integrins is necessary to enable migration (45). CCBP2 gene encodes a $ß$ chemokine receptor. Chemokines and their receptormediated signal transduction are critical for the recruitment of effector immune cells to the inflammation site (46). A specific role for FGFR4 is not well established in cancer, but altered expression has been documented in breast, lung, pancreatic and prostate cancers (47). The FGF/FGFR receptor (FGFR) signaling pathway plays a pivotal role in cellular biology, being involved in differentiation, angiogenesis and motility (48-50). Therefore, genes and proteins up- and down-regulated by K-ras oncogene are considered to be important for tumorigenesis in K-ras Tg mice.

In conclusion, our results suggest that overexpression of transgene plays an important role in the carcinogenesis in $\mathrm{K}$-ras mice. Genes and proteins related to carcinogenesis or $\mathrm{K}$-ras mediated lung cancer are considered to be the candidate genes responsible for the enhanced carcinogenesis in the $\mathrm{K}$-ras $\mathrm{Tg}$ mice.

\section{Acknowledgements}

This study was supported by a grant (08162-510) from Korea Food and Drug Administration and by the Korea Research Foundation Grant funded by the Korean Government (2006-E00119) and by a grant (ROI-2006-000-10145-0) from the KOSEF. D.-Y. Yu was supported by the program for Developing New Technology on Incurable Disease of Seoul City (NSW 0010612).

\section{References}

1. Kerr KM: Pulmonary preinvasive neoplasia. J Clin Pathol 54: 257-271, 2001.

2. Shields JM, Pruitt K, McFall A, Shaub A and Der CJ: Understanding Ras: 'it ain't over 'til it's over'. Trends Cell Biol 10: $147-154,2000$

3. Campbell SL, Khosravi-Far R, Rossman KL, Clark GJ and Der CJ: Increasing complexity of Ras signaling. Oncogene 17: 1395-1413, 1998.

4. Risques RA, Moreno V, Ribas M, Marcuello E, Capella G and Peinado MA: Genetic pathways and genome-wide determinants of clinical outcome in colorectal cancer. Cancer Res 63: 7206-7214, 2003.

5. Wu JT, Kakar S, Nelson RL, et al: Prognostic significance of DCC and p27Kip1 in colorectal cancer. Appl Immunohistochem Mol Morphol 13: 45-54, 2005.

6. Sawabu N, Watanabe H, Yamaguchi Y, Ohtsubo K and Motoo Y: Serum tumor markers and molecular biological diagnosis in pancreatic cancer. Pancreas 28: 263-267, 2004.

7. Wang JY, Hsieh JS, Chang MY, et al: Molecular detection of APC, K-ras, and p53 mutations in the serum of colorectal cancer patients as circulating biomarkers. World J Surg 28: 721-726, 2004.

8. Sugio K, Osaki T, Oyama T, et al: Genetic alteration in carcinoid tumors of the lung. Ann Thorac Cardiovasc Surg 9: 149-154, 2003

9. Kissil JL, Walmsley MJ, Hanlon L, et al: Requirement for Rac1 in a K-ras induced lung cancer in the mouse. Cancer Res 67 : 8089-8094, 2007.
10. Malkinson AM: Molecular comparison of human and mouse pulmonary adenocarcinomas. Exp Lung Res 24: 541-555, 1998.

11. Hanson LA, Nuzum EO, Jones BC, Malkinson AM and Beer DG: Expression of the glucocorticoid receptor and K-ras genes in urethan-induced mouse lung tumors and transformed cell lines. Exp Lung Res 17: 371-387, 1991.

12. Pan YH, Nuzum EO, Hanson LA and Beer DG: Ki-ras activation and expression in transformed mouse lung cell lines. Mol Carcinog 3: 279-286, 1990.

13. You M, Candrian U, Maronpot RR, Stoner GD and Anderson MW: Activation of the $\mathrm{Ki}$-ras protooncogene in spontaneously occurring and chemically induced lung tumors of the strain A mouse. Proc Natl Acad Sci USA 86: 3070-3074, 1989.

14. Vojtek $A B$ and Der CJ: Increasing complexity of the Ras signaling pathway. J Biol Chem 273: 19925-19928, 1998.

15. Khosravi-Far R, Campbell S, Rossman KL and Der CJ: Increasing complexity of Ras signal transduction: involvement of Rho family proteins. Adv Cancer Res 72: 57-107, 1998.

16. McCormick F: Signalling networks that cause cancer. Trends Cell Biol 9: M53-M56, 1999.

17. Tuveson DA and Jacks T: Modeling human lung cancer in mice: similarities and shortcomings. Oncogene 18: 5318-5324, 1999.

18. Wang AG, Moon HB, Lee MR, et al: Gender-dependent hepatic alterations in H-ras 12V transgenic mice. J Hepatol 43: 836-844, 2005.

19. Frith $\mathrm{CH}$ and Ward JM: A morphologic classification of proliferative and neoplastic hepatic lesions in mice. J Environ Pathol Toxicol 3: 329-351, 1979.

20. Qian WJ, Liu T, Monroe ME, et al: Probability-based evaluation of peptide and protein identifications from tandem mass spectrometry and SEQUEST analysis: the human proteome. J Proteome Res 4: 53-62, 2005.

21. Aviel-Ronen S, Blackhall FH, Shepherd FA and Tsao MS: K-ras mutations in non-small-cell lung carcinoma: a review. Clin Lung Cancer 8: 30-38, 2006.

22. Chen B, Johanson L, Wiest JS, Anderson MW and You M: The second intron of the $\mathrm{K}$-ras gene contains regulatory elements associated with mouse lung tumor susceptibility. Proc Natl Acad Sci USA 91: 1589-1593, 1994.

23. Devereux TR, Anderson MW and Belinsky SA: Role of ras protooncogene activation in the formation of spontaneous and nitrosamine-induced lung tumors in the resistant $\mathrm{C} 3 \mathrm{H}$ mouse. Carcinogenesis 12: 299-303, 1991.

24. Herzog CR, Lubet RA and You M: Genetic alterations in mouse lung tumors: implications for cancer chemoprevention. J Cell Biochem 28-29: 49-63, 1997.

25. Wang Y, Zhang Z, Lubet RA and You M: A mouse model for tumor progression of lung cancer in ras and p53 transgenic mice. Oncogene 25: 1277-1280, 2006.

26. Toyoda H, Komurasaki T, Uchida D, et al: Epiregulin. A novel epidermal growth factor with mitogenic activity for rat primary hepatocytes. J Biol Chem 270: 7495-7500, 1995.

27. Torring N, Jorgensen PE, Sorensen BS and Nexo E: Increased expression of heparin binding EGF (HB-EGF), amphiregulin, TGF alpha and epiregulin in androgen-independent prostate cancer cell lines. Anticancer Res 20: 91-95, 2000.

28. Baba I, Shirasawa S, Iwamoto R, et al: Involvement of deregulated epiregulin expression in tumorigenesis in vivo through activated Ki-Ras signaling pathway in human colon cancer cells. Cancer Res 60: 6886-6889, 2000.

29. Zhu Z, Kleeff J, Friess H, et al: Epiregulin is Up-regulated in pancreatic cancer and stimulates pancreatic cancer cell growth. Biochem Biophys Res Commun 273: 1019-1024, 2000.

30. Alyaqoub FS, Liu Y, Tao L, Steele VE, Lubet RA and Pereira MA: Modulation by bexarotene of mRNA expression of genes in mouse lung tumors. Molecular Carcinog 47: 165-171, 2008.

31. Aderem A and Ulevitch RJ: Toll-like receptors in the induction of the innate immune response. Nature 406: 782-787, 2000 .

32. Takeuchi $\mathrm{O}$ and Akira S: Toll-like receptors; their physiological role and signal transduction system. Int Immunopharmacol 1: $625-635,2001$

33. Murata M: Activation of Toll-like receptor 2 by a novel preparation of cell wall skeleton from Mycobacterium bovis BCG Tokyo (SMP-105) sufficiently enhances immune responses against tumors. Cancer Sci 99: 1435-1440, 2008.

34. Drickamer K: C-type lectin-like domains. Curr Opin Struct Biol 9: 585-590, 1999 
35. Iikura M, Suto H, Kajiwara N, et al: IL-33 can promote survival, adhesion and cytokine production in human mast cells. Lab Invest 87: 971-978, 2007.

36. Brauker JH, Trautman MS and Bernfield M: Syndecan, a cell surface proteoglycan, exhibits a molecular polymorphism during lung development. Dev Biol 147: 285-292, 1991.

37. Toyoshima E, Ohsaki Y, Nishigaki Y, Fujimoto Y, Kohgo Y and Kikuchi K: Expression of syndecan-1 is common in human lung cancers independent of expression of epidermal growth factor receptor. Lung Cancer 31: 193-202, 2001.

38. Shah L, Walter KL, Borczuk AC, et al: Expression of syndecan-1 and expression of epidermal growth factor receptor are associated with survival in patients with nonsmall cell lung carcinoma. Cancer 101: 1632-1638, 2004.

39. Yi F, Jaffe R and Prochownik EV: The CCL6 chemokine is differentially regulated by c-Myc and L-Myc, and promotes tumorigenesis and metastasis. Cancer Res 63: 2923-2932, 2003.

40. Khambata-Ford S, Garrett CR, Meropol NJ, et al: Expression of epiregulin and amphiregulin and K-ras mutation status predict disease control in metastatic colorectal cancer patients treated with cetuximab. J Clin Oncol 25: 3230-3237, 2007.

41. Le Provost F, Cassy S, Hayes H and Martin P: Structure and expression of goat GLYCAM1 gene: lactogenic-dependent expression in ruminant mammary gland and interspecies conservation of the proximal promoter. Gene 313: 83-89, 2003.

42. Hynes RO: Integrins: bidirectional, allosteric signaling machines. Cell 110: 673-687, 2002.
43. Ozaki T, Irie K and Sakiyama S: Molecular cloning and cell cycle-dependent expression of a novel gene that is homologous to cdc37. DNA Cell Biol 14: 1017-1023, 1995.

44. Zhang K, Dion N, Fuchs B, et al: The human homolog of yeast SEP1 is a novel candidate tumor suppressor gene in osteogenic sarcoma. Gene 298: 121-127, 2002

45. Chang CC, Shih JY, Jeng YM, et al: Connective tissue growth factor and its role in lung adenocarcinoma invasion and metastasis. J Natl Cancer Inst 96: 364-375, 2004.

46. Nibbs RJ, Wylie SM, Pragnell IB and Graham GJ: Cloning and characterization of a novel murine beta chemokine receptor, D6. Comparison to three other related macrophage inflammatory protein-1alpha receptors, CCR-1, CCR-3, and CCR-5. J Biol Chem 272: 12495-12504, 1997.

47. Powers CJ, McLeskey SW and Wellstein A: Fibroblast growth factors, their receptors and signaling. Endocr Relat Cancer 7: 165-197, 2000.

48. Bange J, Prechtl D, Cheburkin Y, et al: Cancer progression and tumor cell motility are associated with the FGFR $4 \operatorname{Arg}(388)$ allele. Cancer Res 62: 840-847, 2002.

49. Shah RN, Ibbitt JC, Alitalo K and Hurst HC: FGFR4 overexpression in pancreatic cancer is mediated by an intronic enhancer activated by HNF1alpha. Oncogene 21: 8251-8261, 2002.

50. Nakamura N, Iijima T, Mase K, et al: Phenotypic differences of proliferating fibroblasts in the stroma of lung adenocarcinoma and normal bronchus tissue. Cancer Sci 95: 226-232, 2004. 